INTERNATIONAL JOURNAL OF MULTIDisciplinARY RESEARCH AND ANALYSis

ISSN(print): 2643-9840, ISSN(online): 2643-9875

Volume 04 Issue 07 July 2021

DOI: 10.47191/ijmra/v4-i7-12, Impact Factor: 6.072

Page No.- $945-959$

\title{
Handling of Quality Corruption Case by the Prosecutor as Part of Prevention Measure
}

\author{
Budi Triono ${ }^{1}$, Taufiqurrohman Syahuri, $\mathrm{SH}, \mathrm{MH}^{2}$ \\ ${ }^{1}$ Master of law study program "veteran" national development university Jakarta faculty of law \\ ${ }^{2}$ Supervisor, master of law study program "veteran" national development university Jakarta faculty of law
}

ABSTRACT: Enforcement of quality corruption cases by the Prosecutor's Office of the Republic of Indonesia as one of the law enforcers who has the main task and function in law enforcement, one of which is related to eradicating corruption. Seeing the importance of the position of the prosecutor's office in law enforcement specifically to combat corruption, it is important to conduct an assessment of the legal politics of eradicating corruption at the prosecutor's office in particular. The conclusion of this paper is to first discuss how the pattern of handling corruption with quality by the Attorney General's Office of the Republic of Indonesia through Institutional Politics policies that they embody in the regulations of instructions and letters of the attorney general relates to improving the performance of handling corruption cases and efforts to eradicate corruption Second, The Prosecutor's Office of the Republic of Indonesia as a government institution indirectly in making legal policies has the nuances of policies taken by the government and is based on related legal rules. As for some of the prosecutor's policies in eradicating corruption that are in line with the government's intent, namely the formation of a TP4 Team, establishing a corruption-free zone, enforcing corruption that is not selective, educating the dangers of corruption for state activities and emphasizing on handling cases with legal economic aspects the basis for consideration is the principle of benefit and the principle of proportionality in order to support development programs and smoothness in the life of the nation and state.

KEYWORDS: Legal Politics, Corruption, Prosecutors

\section{INTRODUCTION}

\section{A. Background}

Corruption cases in Indonesia cannot be separated from the print media and electronic media coverage related to the development of corruption cases being handled by law enforcement as well as new corruption cases that have emerged and are revealed by law enforcement almost every time adorn the print and electronic media coverage in Indonesia. From this print and electronic media coverage, it creates anger and feelings of disappointment towards corruptors, which are generally mostly carried out by state servants or public servants and protectors and the reactions of legal experts and various parties who argue about the causes of corruption, about the dangers of corruption, regarding acts of deep-rooted and structured corruption, and even a network of corruption that is increasingly widespread and rampant in various spheres of social, political, and economic services. $^{1}$

In addition, corruption is a serious threat to life because it violates the social and economic rights of the community, so corruption should be a crime that will affect the welfare of the nation and state, especially the people in it. In a concept like this, along with the scope of reforms that have been implemented by the State of Indonesia, how important is the law as a means of protection (social defense) to regulate the life of the community, nation and state in various aspects of life such as politics and the economy.

Cindy Rizka Tirzani Koesoemo, argues that:

\footnotetext{
${ }^{1}$ murwiyanto, effectiveness of the prosecutor's office in eradicating corruption crimes and refunding state losses due to corruption, published in

https://dspace.uii.ac.id/bitstream/handle/123456789/9136/tesis\%20murwiyanto.pdf?sequence=1\&isallowed=y, accessed on 01 march 2021.
} 


\section{Handling of Quality Corruption Case by the Prosecutor as Part of Prevention Measure}

"Corruption is a threat to democratic principles, which uphold transparency, accountability and integrity, as well as the security and stability of the Indonesian nation. ${ }^{2}$

Edi Setiadi, argues that:

"Democracy itself, which was considered complete after the 1998 Reformation, became meaningless when corruption still reigned in Indonesia in almost every aspect of the life of the nation and state. The problem of corruption in Indonesia (collusion and nepotism are part of corruption) is a very complicated problem. Almost all lines of life have been affected by the epidemic of corruption. The fierce attitude of law enforcement officers is not strong enough to curb corruption. Corruption seems to have become a culture, besides the public's doubts about the government's seriousness in eradicating corruption, adds to the problems for law enforcement officers". ${ }^{3}$

The Indonesian government's efforts in eradicating corruption in the general government and development sectors have in fact not been followed by real and serious steps by the government, including law enforcement officers in implementing and enforcing the law. Likewise, the emergence of intervention and influence from other parties in the completion of the judicial process actually weakens efforts to eradicate corruption in order to realize good governance. The problem of corruption and dissecting the problem is something that is very urgent, because corruption cases are almost always related to power and position and the people involved in it. In addition, corrupt practices are usually carried out in the form of engineering as if justified by law and there is even legal manipulation. ${ }^{4}$

Mohammad Saihu also argues that:

"In realizing good governance in eradicating corruption, we must pay attention to the principles of good governance, so that it can affect the credibility and capability of the government. The Indonesian nation is currently being hit by a crisis of confidence in every segment of the life of the nation and state, both in the social, political, economic, trade, financial and industrial fields. A crisis of confidence occurs in economic institutions, government institutions, both executive, judicial and legislative institutions, financial institutions, banks and non-banks as well as party institutions, this is because a good, clean and free government has not been created. After the era of reform and regional autonomy, Corruption is actually increasing and not only happening in central government agencies but also occurring within local government agencies. More ironically, along with the implementation of regional autonomy, corruption has also been decentralized safely and fertilely by regional officials. Autonomy is also a play on the meaning of "for-corruption" 5

In theoretical and practical discourse, the legislation has a function as an instrument (tool/means) in law enforcement efforts. This shows that the tools/means or instruments for preventing, tackling, and taking action against corruption are already available. The urge to eradicate corruption has resonated, but in reality the completion of corruption crimes, especially those that attract public attention, the results have not been satisfactory. The performance of the public prosecutor's office in enforcing the law on corruption is considered by the community not to be optimal and maximal as demanded by the community. ${ }^{6}$

The (good) law enforcement system is thus closely related to the harmony between the rules and actual behavior. In life, humans basically have certain views about what is good and what is bad. This view is embodied in the values he adheres to. In law enforcement, these values must be compatible and in accordance with the actions taken. Furthermore, these values need more concrete elaboration, because the nature of values is usually still abstract. Meanwhile, a more concrete elaboration is contained in legal rules that are commands, prohibitions or things that are allowed. These legal rules are then used as guidelines for behavior, attitudes, and actions that are considered appropriate or appropriate. Behavior, attitude, ${ }^{7}$

\footnotetext{
${ }^{2}$ cindy rizka tirzani koesoemo, the existence of the corruption eradication commission (kpk) in handling the investigation and prosecution of criminal acts of corruption, published in the journal of lex crimen volume. vi/number. 1/jan-feb/ 2017, p. 1.

${ }^{3}$ edi setiadi, enforcement of criminal law against corruption cases in creating clean government, published in the pulpit journal number. 4th xvi oct. - dec. $2000-305$, pp. 1.

${ }^{4}$ asrianto zainal, law enforcement of corruption crimes by the attorney general's office, published in ejournal.iainkendari.ac.id alizzah article view, accessed on 09 march 2021, at 09:30 wib.

${ }^{5}$ mohammad saihu, law summit iii: eradicating kkn indiscriminately to its roots march-april edition, (jakarta: khn newsletter 2004), page 6.

${ }^{6}$ muhammad afzal, effectiveness of corruption enforcement in the aceh high court based on law no. 20 of 2001 ", published inhttps://repository.ar-raniry.ac.id/id/eprint/15315/1/muhammad\%20afzal\%2c\%20140106038\% 2c\% 20fsh\%2c\%20ih\%2c\% 2008216 7420403.pdf, accessed on march 10, 2021, at 14:30 wib.

7 asrianto zainal, loc.cit
} 


\section{Handling of Quality Corruption Case by the Prosecutor as Part of Prevention Measure}

RomliAtmasasmita argues that:

"In Indonesia, law enforcement is a term that is not foreign to the public, especially in relation to the problem of applying criminal law (procedures). It is not surprising that law enforcement in Indonesia is still unclear. In addition, law enforcement also means the application of criminal law (procedures) in the settlement of criminal cases. Thus, law enforcement as part of the criminal justice system requires a single unit of law enforcement officers tasked with taking action against violators of the criminal act of corruption. This means that as a law enforcement process it must consist of several stages starting from investigation and investigation, arrest, detention, preliminary examination, prosecution and trial, ${ }^{8}$

Law enforcement as a process is actually an application of discretion that involves making decisions that are not strictly regulted by the rule of law, but contain elements of personal judgment. On this basis, it can be understood that interference with law enforcement may occur if there is a mismatch of values/rules and patterns of behavior. This happens because of the incompatibility between the values that are firmly held with disruptive patterns of undirected behavior. ${ }^{9}$

Muladi argues that: "Law enforcement as a systematic process, then criminal law enforcement appears as the application of criminal law (criminal law application) which involves various structural subsystems, namely the Police, Prosecutors, Courts and Corrections including legal advisory institutions. In this context, the application of criminal law must be viewed from 3 (three) dimensions. The first dimension of the application of criminal law is seen from the normative system, namely the application of the entire rule of law that describes social values, which are supported by criminal sanctions. The second dimension, the application of criminal law is seen as an administrative system that includes interaction between institutions of law enforcement apparatus which are the judicial subsystems above". ${ }^{10}$

M. Yahya Harahap argues that: "The most urgent and fundamental problem in law enforcement actually lies in the factors that influence it, including:

1. statutory factors (law),

2. law enforcement factors

3. factor of facilities or facilities,

4. community factors, and

5. Cultural factors". ${ }^{11}$

These five factors are interrelated with one another, given that they are the essence of law enforcement and are a benchmark for the effectiveness of law enforcement in Indonesia. The existence of these factors can also affect law enforcement positively and negatively. However, of all these factors, the law enforcement factor is the focal and central point. This is because the implementation of laws or regulations is under the responsibility of law enforcers, while these law enforcers are considered by the community as legal role models. ${ }^{12}$

As a form of seriousness in maximum efforts to eradicate corruption in Indonesia, various policies have been issued to make Indonesia free from corruption. The President has also issued a number of instructions and directives to prevent and eradicate corruption, namely taking the necessary steps according to their respective duties, functions and authorities in the context of preventing and eradicating corruption guided by strategies that include: ${ }^{13}$

1. Prevention Strategy;

2. Law Enforcement Strategy;

3. Legislation Strategy;

4. Strategy for International Cooperation and Safeguarding of Corruption Proceeds;

5. Anti-Corruption Culture and Education Strategy;

6. Reporting Mechanism Strategy.

${ }^{8}$ romli atmasasmita, strategy for guiding criminals in the context of law enforcement in indonesia. (bandung: alumni, 1982), p. 69-70.

${ }^{9}$ muhammad afzal, loc.cit

${ }^{10}$ muladi, capita selecta of the criminal justice system. (semarang: diponegoro university publishing agency, 2002 ), p. 40.

${ }^{11} \mathrm{~m}$. yahya harahap, discussion of problems and implementation of the criminal procedure code. (jakarta: sinar graphic, 2002), p. 90

${ }^{12}$ asrianto zainal, loc.cit

${ }^{13}$ presidential instruction of the republic of indonesia number 9 of 2011, instruction of the president of the republic of indonesia number 17 of 2011. 


\section{Handling of Quality Corruption Case by the Prosecutor as Part of Prevention Measure}

The Prosecutor's Office as one of the law enforcement agencies that has a strategic position in law enforcement is required to play a greater role in upholding the rule of law, protecting legal interests, violating human rights and eradicating corruption. The Prosecutor's Office is also required to participate in maintaining and upholding the authority of the government and the state, as well as protecting the interests of the community through optimal, real and reliable law enforcement efforts by heeding religious norms, decency, decency and applicable laws and regulations and must explore values. humanity, law and justice that live in society. Eradication of criminal acts of corruption through law enforcement mechanisms must be carried out more intensively, effectively, firmly, seriously. In eradicating corruption, ${ }^{14}$

In eradicating corruption/law enforcement related to corruption, there are several institutions that are given the authority, namely:

1. The Corruption Eradication Commission;

2. The National Police of the Republic of Indonesia;

3. Prosecutor's Office of the Republic of Indonesia;

4. Judicial institutions under the Supreme Court; ${ }^{15}$

Dellyana, Shant argues that:

"Law enforcement is an effort to realize the ideas and legal concepts that the people expect to become a reality. Law enforcement is a process that involves a lot of law enforcement carried out by law enforcement officers, namely, the Police, Prosecutors, Courts, Advocates, and Correctional Institutions. The law enforcement officers are a sub-system of the criminal justice system. The Prosecutor's Office as one of the law enforcers in eradicating corruption which is a sub-system of the criminal justice system must strive to improve the professionalism of the apparatus, as well as increase the role of the Prosecutor's Office in eradicating corruption. It must be understood that the eradication of corruption in a broad dimension is not just the enforcement of written rules in the law, ${ }^{16}$

From the opinion above, that the Attorney General of the Republic of Indonesia in the opening ceremony of the technical working meeting for the field of special crimes in 2018, stated that: "In the midst of the various modus operandi of criminal acts of corruption which tend to be increasingly rampant and occult, even transforming is no longer just a common crime. called white-collar crime, which was originally known to be committed among educated and ruling elites, but has now developed into a corporate crime, congregational and even cross-country. In addition, the process of legal development is also increasingly dynamic which is marked by various changes in legal norms, and is faced with a number of obstacles due to disharmony of laws and regulations and technical guidelines of each judicial institution. all of which bring significant changes that color and affect law enforcement efforts. Therefore, the paradigm of intelligent law enforcement to eradicate corruption and quality law enforcement patterns to eradicate corruption are essential factors to encourage the realization of success in optimally accelerating corruption eradication. Therefore, it is necessary to understand that the handling of corruption cases must be carried out with full initiative and innovation, by always presenting various approaches that emphasize efficiency and effectiveness, and can be applied and useful to support the success of the Prosecutor's Office in producing efficient and effective outputs. Departing from the orientation of the quality of handling cases of corruption, ${ }^{17}$

In handling corruption crimes as stated in Article 30 paragraph (1) letter d of Law Number 16 of 2004, it is stated that: Prosecutors play a role in investigating certain criminal acts based on the Act. ${ }^{18}$

The task carried out by the Prosecutor in the investigation, namely collecting data and supporting information in corruption, must be based on Law Number 20 of 2001 concerning the eradication of corruption, which is binding, indiscriminate and without regard to the number of large or small. funds that are corrupted so that they must still be punished in order to get a deterrent effect. The policy issued by the Attorney General's Office in handling petty corruption cases is that the handling of corruption is prioritized on the disclosure of cases that are big fish (large scale, seen from the perpetrators and or the value of state financial losses) and still going on (corruption acts carried out continuously or continuously). sustainable), so that in law enforcement it prioritizes a sense of community justice,

14 muhammad afzal, loc.cit

15 ibid

${ }^{16}$ dellyana, shant, the concept of law enforcement, (liberty: yogyakarta, 1988), p. 32

${ }^{17}$ the attorney general's team, speech by the attorney general at the opening ceremony of the 2018 technical working meeting for special crimes, was published in https://www.kejaksaan.go.id/pidato.php ?idu=0\&id=206\& p=8, accessed on march 15, 2021.

${ }^{18}$ law of the republic of indonesia number 16 of 2004 article 30 paragraph (1). 


\section{Handling of Quality Corruption Case by the Prosecutor as Part of Prevention Measure}

Regarding the handling of corruption cases that are big fish, among others, the corruption case of PT Asuransi Jiwasraya. The alleged corruption case of PT Asuransi Jiwasraya is said to have caused state losses of up to Rp. 16.81 trillion. The state losses consist of losses due to investment in shares of Rp. 4.65 trillion and losses due to mutual fund investment of Rp. 12.16 trillion". ${ }^{19}$

Then the case of the Corruption Crime of Financial Management and Investment Funds at PT. Asuransidiwasraya (Persero) was transferred to the Corruption Court at the Central Jakarta District Court divided into 6 (six) files, namely in the name of each of the Defendants: ${ }^{20}$

a. The Defendant BENY TJOKROSAPUTRO, President Director of PT Hanson International Tbk;

b. The defendant HERU HIDAYAT, President Commissioner of PT Trada Alam Minera Tbk;

c. The defendant HARY PRASETYO, Finance Director of PT. Asuransiliwasraya (Persero) for the period 2013-2018;

d. Defendant Dr. HENDRISMAN RAHIM, President Director of PT. Asuransi Jiwasraya (Persero) for the period 2008-2018;

e. The defendant SYAHMIRWAN, SE., former Head of the Financial Investment Division of PT. Asuransi Jiwasraya (Persero);

f. Defendant JOKO HARTONO TIRTO Director of PT Maxima Integra;

The verdict of the judge at the Corruption Court at the Central Jakarta District Court is as follows: ${ }^{21}$

a. Central Jakarta District Court Decision Number: 29/Pid.Sus-TPK/2020/PN.Jkt.Pst dated October 26, 2020 on behalf of the Defendant BENNY TJOKROSAPUTO:

- To declare that the Defendant BENNY TJOKROSAPUTRO is proven legally and convincingly guilty of committing a criminal act of corruption together and committing the crime of money laundering as stated in the First Primary and the Second Primary indictment

- Sentencing the Defendant therefore with life imprisonment;

- Imposing additional penalties against the Defendant to pay compensation to the State in the amount of Rp. $6,078,500,000,000,-$ (six trillion seventy eight billion five hundred million rupiah), if the convict does not pay the replacement money at the latest within 1 (one) month after the court's decision has permanent legal force, his assets will be confiscated by the prosecutor and auctioned off to cover the replacement money;

- Determined that the evidence confiscated from the Defendant was confiscated for the State and the rest was used for the Dr. HENDRISMAN RAHIM, HARY PRASETYO, MBA, SYAHMIRWAN, SE., JOKO HARTONO TIRTO and HERU HIDAYAT.

b. Central Jakarta District Court Decision Number: 30/Pid.Sus-TPK/2020/PN.Jkt.Pst dated October 26, 2020 on behalf of the Defendant HERU HIDAYAT:

- To declare that the Defendant HERU HIDAYAT is legally and convincingly proven guilty of committing a criminal act of corruption together and committing the crime of money laundering as stated in the First Primary and the Second and Third Primary indictments;

- Sentencing the Defendant therefore with life imprisonment;

- Imposing additional penalties against the Defendant to pay compensation to the State in the amount of Rp. $10,728,783,375,000$,- (ten trillion seven hundred twenty-eight billion seven hundred eighty-three million three hundred seventy-five thousand rupiah), if the convict does not pay the replacement money no later than 1 (one) month after the Court's decision is obtained. permanent legal force, the assets are confiscated by the Prosecutor and auctioned off to cover the replacement money;

- Determined that the evidence confiscated from the Defendant was confiscated for the State and the rest was used for the case of JOKO HARTONO TIRTO, Dr. HENDRISMAN RAHIM, HARY PRASETYO, MBA, SYAHMIRWAN, SE., and BENNY TJOKROSAPUTO.

19 tsarina maharani, jiwasraya corruption case investigation, ago confiscates idr https://national.kompas.com/read/2020/07/02/17221671/investigation-case-korupsi-jiwas trillion, accessed on march 17,2021 , at 17:30 wib.

${ }^{20}$ the indictment of the public prosecutor in the corruption case of pt asuransi jiwasraya. tbk.

${ }^{21}$ central jakarta district court, "sipp - central jakarta district court, http://sipp.pn-jakartacenter.go.id/index.php/detil_perkara, accessed on march 20, 2021, at 21:30 wib. 


\section{Handling of Quality Corruption Case by the Prosecutor as Part of Prevention Measure}

c. Central Jakarta District Court Decision Number: 31/Pid.Sus-TPK/2020/PN.Jkt.Pst dated October 12, 2020 on behalf of the Defendant HARY PRASETYO, MBA.

- Stating the Defendant HARY PRASETYO, MBA. proven legally and convincingly guilty of committing the crime of "CORRUPTION DONE COLLECTIVELY", as stated in the primary indictment;

- Sentencing the Defendant therefore with life imprisonment;

- Determined that the evidence confiscated from the Defendant was confiscated for the State and the rest was used for the Dr. HENDRISMAN RAHIM and SYAHMIRWAN, SE. ;

d. Central Jakarta District Court Decision Number: 32/Pid.Sus-TPK/2020/PN.Jkt.Pst dated October 12, 2020 on behalf of the Defendant Dr. HENDRISMAN RAHIM:

- Stating the Defendant Dr. HENDRISMAN RAHIM was proven guilty of committing a criminal act of corruption together as stated in the Primary indictment;

- Sentencing the Defendant therefore with life imprisonment;

- Determined that the evidence confiscated from the Defendant was confiscated for the State and the rest was used for the case of SYAHMIRWAN, SE. ;

e. Central Jakarta District Court Decision Number: 33/Pid.Sus-TPK/2020/PN.Jkt.Pst dated October 12, 2020 on behalf of the Defendant SYAHMIRWAN, SE. :

- Declaring that the Defendant SYAHMIRWAN, SE was found guilty of committing a criminal act of corruption together as stated in the Primary indictment;

- Sentencing the Defendant therefore with life imprisonment;

- Determine that the evidence confiscated from the Defendant is confiscated for the State;

f. Central Jakarta District Court Decision Number: 34/Pid.Sus-TPK/2020/PN.Jkt.Pst dated October 12,2020 on behalf of the Defendant JOKO HARTONO TIRTO:

- To declare that the Defendant, JOKO HARTONO TIRTO, was found guilty of committing a criminal act of corruption together as stated in the Primary indictment;

- Sentencing the Defendant therefore with life imprisonment;

- Determined that the evidence confiscated from the Defendant was in the form of confiscated assets for the State and in the form of documents/the rest was used for the case of HERU HIDAYAT and BENNY TJOKROSAPUTRO";

Whereas in the previous trial, specifically for the 4 (four) Defendants mentioned above, the Public Prosecutor Team has been prosecuted as follows: ${ }^{22}$

1. Defendant BENNY TJOKROSAPUTRO

2. Defendant HERU HIDAYAT

3. The defendant HARY PRASETYO, MBA. prosecuted with the following sentence: imprisonment for life with an order that the defendant remains detained in the Detention Center; A fine of IDR 1,000,000,000 (one billion rupiah) for a subsidiary 6 (six) months in prison;

4. Defendant Dr. HENDRISMAN RAHIM was charged with the following sentences: The prison sentence was reduced to 20 (twenty) as long as the defendant was in temporary detention with the order that the defendant remained detained in the Detention Center; A fine of IDR 1,000,000,000 (one billion rupiah) for a subsidiary 6 (six) months in prison;

5. Defendant SYAHMIRWAN, SE. prosecuted with the following sentences: imprisonment for 18 (eighteen) reduced as long as the defendant is in temporary detention with an order that the defendant remains detained in the Detention Center; fined Rp. 1,000,000,000 ;

6. The defendant JOKO HARTONO TIRTO was charged with the following sentences: imprisonment for life with an order that the defendant remain detained in the Detention Center; A fine of IDR 1,000,000,000 (one billion rupiah) for a subsidiary 6 (six) months in prison;

\footnotetext{
${ }^{22}$ central jakarta district court number: 30/pid.sus-tpk/2020/pn.jkt.pst dated 22 may 2020, central jakarta district court number: 32/pid.sus-tpk/2020/pn.jkt.pst 22 may 2020, central jakarta district court number: 33/pid.sus-tpk/ 2020/pn.jkt.pst dated may 22, 2020, and central jakarta district court number: 34/pid.sus-tpk/2020/pn.jkt.pst may 27, 2020 ;
} 


\section{Handling of Quality Corruption Case by the Prosecutor as Part of Prevention Measure}

The demands of the Prosecutor and the Judge's Decision are in the form of maximum punishment and impoverish the perpetrators in the corruption case of PT. Asuransiliwasraya (Persero) can also have a preventive function, namely the emergence of a deterrent effect for the community to commit criminal acts of corruption.

The Prosecutor's Office as a law enforcement agency holds a large mandate ranging from investigation, investigation, prosecution to execution, law enforcement not only imprisons the perpetrators but also returns state finances that have been deviated. Attorney General ST Burhanuddin stated that law enforcement officials began to adjust the orientation of law enforcement that had been carried out so far. If previously using the approach of pursuing and punishing the perpetrators through imprisonment (follow the suspect), now the orientation must be accompanied by a follow the money and follow the asset approach. Law enforcement policies must ensure that punishments must be able to provide a deterrent effect, both in the criminal sector and the perpetrator's economy. ${ }^{23}$

Based on the description above, the author is interested in discussing some of the problems that exist in the research with the title. "Quality Corruption Case Handling by the Prosecutor's Office as Part of Prevention Efforts"

\section{B. Problem Formulation}

Based on the background above, the research problems in this thesis can be formulated as follows:

1. How is the quality of corruption cases handled by the Indonesian Attorney General's Office?

2. What is the implementation of the quality handling of corruption cases by the Indonesian Prosecutor's Office?

\section{RESEARCH METHODOLOGY}

This study uses a normative legal research methodology with the Statute Approach, Case Approach and Conceptual Approach. With this approach, the author will explore and obtain information from various aspects of the issue being studied. ${ }^{24}$

Peter Mahmud Marzuki defines Legal Research as a process to find the rule of law, legal principles, and legal doctrines to be able to answer the legal issues at hand, with the result to be achieved is to give prescriptions about what should be. ${ }^{25}$

The type of research in this legal research is normative or doctrinal legal research. According to Terry Hutchinson as quoted by Peter Mahmud Marzuki defines that doctrinal legal research is as follows:

"Doctrinal research: research wich provides a systematic exposition of the rules governing a particular legal category, analyzes the relationship between rules, explains areas of difficulty and, perhaps, predicts future development."

(Doctoral research is research that provides a systematic explanation of the rules governing a particular category of law, analyzes the relationship between regulations, explains areas of difficulty and perhaps predicts future development). Normative legal research, which is another name for doctrinal legal research, is also referred to as library research or document study because this research is conducted or aimed only at written regulations or other legal materials. In essence, research is carried out by examining library materials or secondary data consisting of primary legal materials, secondary legal materials and tertiary legal materials. ${ }^{26}$

The type of data used by the author in this study is secondary data. Secondary data is data that is not obtained directly from the first source. Secondary data obtained from library materials which include documentary materials, scientific writings, books, and other written sources based on their binding strength are divided into:

1. Primary Legal Materials, namely the basic rules, statutory regulations, among others:

1) Law Number 31 of 1999 concerning Corruption Crimes.

2) Law Number 20 of 2001 concerning the Eradication of Corruption.

3) Law Number 16 of 2004 concerning the Attorney General's Office of the Republic of Indonesia.

4) Regulation of the Attorney General of the Republic of Indonesia Number: PER-039/A/JA/10/2010 dated October 29, 2010 concerning Administrative and Technical Management of Special Crime Cases.

\footnotetext{
${ }^{23}$ asniovier, attorney general: in order to have a deterrent effect, law enforcement must follow the assets, published in https://www.beritasatu.com/nasional/702149/jaksa-agung-agar-ada-hasil-jera-penegakan-hu kum-harus-follow-the-asset, accessed on march 21, 2021, at 20:25 wib

${ }^{24}$ peter mahmud marzuki (b), loc. cit, p.133.

${ }^{25}$ peter mahmud marzuki (a), legal research revised edition, 12th printing, (jakarta: prenada media group, 2016 ), p. 57.

${ }^{26}$ peter mahmud marzuki. op.cit. thing. 32.
} 


\section{Handling of Quality Corruption Case by the Prosecutor as Part of Prevention Measure}

5) The Instruction of the Attorney General of the Republic of Indonesia Number: INS-002/A/JA/02/2019 dated February 21, 2019 concerning the Pattern for Handling Qualified Special Criminal Cases.

6) Circular Letter of the Attorney General of the Republic of Indonesia Number: SE-001/A/JA/02/2019 dated February 21, 2019 concerning Control of Corruption Crimes.

7) Letter of the Deputy Attorney General for Special Crimes Number: B-845/F/Fjp/05/2018 dated 4 May 2018 concerning Technical Guidelines for the Handling of Qualified Special Crime Cases

8) Letter of the Deputy Attorney General for Special Crimes Number: B-765/F/Fd.1/04/2018 concerning Technical Guidelines for Handling Cases of Criminal Acts of Corruption in the Investigation Stage.

9) Letter of the Deputy Attorney General for Special Crimes No. B-1450/F/Fd.1/08/2018 dated August 23, 2018 regarding Requests for Information Data to PPATK.

2. Secondary Legal Material

Secondary legal materials are materials that are complementary. According to Peter Mahmud Marzuki, secondary materials are all publications on law which are not official documents. Both materials were investigated using document study techniques. The secondary legal materials used are law books, legal dictionaries, legal journals and court decisions related to research but not in the form of official documents.

3. Tertiary Law Material

Tertiary legal materials are materials that provide explanations for primary and secondary legal materials.

The legal materials as described above are analyzed using 3 (three) descriptive techniques to describe legal events regarding ship sinking/burning; comparative technique to compare legal norms governing ship sinking/burning with legal norms regarding the criminal justice system; and argumentative techniques to provide researchers' arguments regarding the policy of sinking/burning ships in the future.

\section{DISCUSSION}

\section{A. Qualified Handling of Corruption Crime Cases by the Indonesian Prosecutor's Office}

The Indonesian people really hope for the function or role of the law and it's implementing institutions in realizing a clean and free state administration from corruption, collusion and nepotism (hereinafter referred to as corruption). Today, almost all development sectors, even in the joints of daily life, people have been infected with corruption. Therefore, the law must appear in front as a powerful tool as well as show direction for efforts to eradicate corruption. ${ }^{27}$

Various laws and regulations governing aspects of eradicating corruption have been enacted. Therefore, only with firm commitments that are consistent and carried out consistently, efforts to eradicate corruption can be carried out in an orderly and orderly manner so that the ideals of realizing a just, prosperous and prosperous society can be achieved.

RomliAtmasasmita, argues that:

"The law is not enough only with the Norm System as stated by Mochtar Kusumaatmadja, and the Behavior System as stated by Satjipto Rahardjo, but also needs to integrate the community's Value System. The value system comes from Pancasila as the soul of the Indonesian nation, hereinafter referred to as Integrative Legal Theory." ${ }^{28}$

Law is not just a collection or summation of regulations, each of which stands alone, but is a legal system. Or a unit consisting of elements that interact with each other functionally and work together to achieve a certain goal. ${ }^{29}$

According to Friedmann, the legal system consists of legal substance, legal structure, and legal culture. ${ }^{30}$ Meanwhile, Mattei is of the opinion that in every legal system, civil law, common law, and socialist law, there are interactions between the rule of professional law, the rule of political law, and the rule of traditional law. ${ }^{31}$ Referring to Mattrei's opinion and if it is connected with Friedmann's opinion, it appears that law enforcement in every legal system will always differ in the interests of

\footnotetext{
${ }^{27}$ Borrowing the term "development" put forward by mochtar kusumaatmadja, functions and development of law in national development, 1976, binacipta, bandung, p. 12.

${ }^{28}$ Ipikp, another side of the accountability of the kpk and anti-corruption activist institutions, gramedia pustaka utama, 2016, jakarta, p. 16.

${ }^{29}$ romli astasasmita, integrative legal theory, second printing, genta yogyakarta, 2012, p. 96.

${ }^{30}$ I. friedmann, the legal system: a social science perspective, rusel sage foundstions, new york, 1975.

31 ugo mattei, theer patterns of law: taxonomy and change in the world's new constitutions, the american journal of comparative law, 1997.
} 


\section{Handling of Quality Corruption Case by the Prosecutor as Part of Prevention Measure}

professionalism, politics, and local traditions. This also shows that law enforcement in each country, including the eradication of corruption, will be chosen according to the conditions of society, geography, and culture.

In law enforcement in Indonesia, especially in eradicating corruption, the view of Integrative Legal Theory is very relevant because the eradication of corruption is seen from a macro perspective, which includes not only legal aspects, but also other aspects, namely economic and political aspects. . ${ }^{32}$

The macro approach to corruption eradication prompted the amendment of Law Number 20 of 2001, which was later amended by Law of the Republic of Indonesia Number 19 of 2019 concerning the Second Amendment to Law Number 30 of 2002 concerning the Corruption Eradication Commission. Even if there are, these changes have not completely shifted from a retributive approach to a macro approach. ${ }^{33}$

With the amendment of Law Number 30 of 2002 concerning the Corruption Eradication Commission into Law of the Republic of Indonesia Number 19 of 2019, which is controversial and has been discussed by various circles of society to this day. Proving that corruption is an extraordinary crime and at the same time is seen as a violation of social and economic rights of the community. Based on these considerations, the social and economic rights of the community require serious attention from the government to prevent and eradicate corruption, both according to good laws and accompanied by the quality of law enforcers who must be demanded to continuously improve the quality of their performance. The government's protection of social rights and economic rights of the community has not been seriously considered in Law Number 31 of 1999 and its amendments, in the sense that the law still focuses on a deterrent effect that has not contributed significantly to the protection of people's social and economic rights that. This reflects that in the legislative process related to eradicating corruption, economic analysis has not been taken into account that puts forward economic principles: maximization, balance, and efficiency. ${ }^{34}$

Today's facts are that Indonesia's investigative, prosecution and judicial institutions for the eradication of corruption are actually more than adequate, starting from the Indonesian Police, the Indonesian Attorney General's Office, the Courts (in th is case the Constitutional Court and Supreme Court), and of course ad hoc institutions that have the authority to coordinate and supervise on the handling of cases of corruption, namely the KPK. For the record, the State Revenue and Expenditure Budget (APBN) allocated in 2014 for all corruption prevention and prosecution institutions reached Rp. 53.46 trillion with the details of each BPK (Rp. 2.9 trillion), BPKP (Rp. 1.26 trillion), KPK (Rp. 0.56 trillion), Polri (Rp. 43.3 trillion), Attorney General's Office (Rp. 3.57 trillion) and MA (Rp. 2.18 trillion). With the budget provided by the state for the interests of the people which is increasing every year, ${ }^{35}$

Looking at the negative impact of corruption, it is necessary to make good law enforcement policies in eradicating corruption. The Attorney General's Office of the Republic of Indonesia as one of the law enforcers who has the main duties and functions in law enforcement, one of which is related to the eradication of corruption. According to Article 2 paragraph (1) of the Law of the Republic of Indonesia Number 16 of 2004 concerning the Prosecutor's Office of the Republic of Indonesia (hereinafter referred to as the Prosecutor's Law) explains that the Prosecutor's Office is a government institution that carries out state power in the field of prosecution and other authorities based on the law. The duties and authorities of the Prosecutor's Office related to the eradication of corruption include: ${ }^{36}$

a) conduct investigations into criminal acts of corruption;

b) carry out the prosecution of criminal acts of corruption;

c) carry out the determination of judges and court decisions on Corruption Crimes that have obtained permanent legal force;

d) supervise the implementation of conditional criminal decisions, supervisory criminal decisions, and parole decisions;

e) complete certain case files and for that purpose can carry out additional examinations before being transferred to the court which in its implementation is coordinated with investigators;

f) through the State Attorney's Office to file a civil lawsuit against a legal event that results in a loss of state finances;

g) Carry out preventive and/or educational efforts related to the eradication of corruption.

\footnotetext{
${ }^{32}$ Ipikp, another side of the accountability of the kpk and anti-corruption activist institutions, gramedia pustaka utama, 2016, jakarta, p. 18.

33 ibid.

${ }^{34}$ Ipikp, another side of the accountability of the kpk and anti-corruption activist institutions, gramedia pustaka utama, 2016, jakarta, p. 27.

${ }^{35}$ Government report on implementation of state revenue and expenditure budget 2014 fiscal year, republic of indonesia, 2014. ${ }^{36}$ law of the republic of indonesia number 16 of 2004 concerning the prosecutor's office of the republic of indonesia.
} 


\section{Handling of Quality Corruption Case by the Prosecutor as Part of Prevention Measure}

Because the direct impact of this corrupt action is felt by the community both socially and economically, many of the rights of the community are snatched away by the corruptors from their actions that cause state losses. , the ease of social activities, access to increased human resources, and the right to improve economic welfare and standard of living with corruption that has had a profound impact on society. It is imperative that prevention and eradication of corruption must show better quality in terms of regulation, sanctions, implementation of eradication and prevention to deter perpetrators of corruption which is an extraordinary crime. and the right to improve economic well-being and standard of living with corruption that has had a profound impact on society. It is imperative that prevention and eradication of corruption must show better quality in terms of regulation, sanctions, implementation of eradication and prevention to deter perpetrators of corruption which is an extraordinary crime. And the right to improve economic well-being and standard of living with corruption that has had a profound impact on society. It is imperative that prevention and eradication of corruption must show better quality in terms of regulation, sanctions, implementation of eradication and prevention to deter perpetrators of corruption which is an extraordinary crime.

\section{B. Implementation of Quality Corruption Cases Handling by the Indonesian Prosecutor's Office}

Based on the Instruction of the Attorney General of the Republic of Indonesia Number: INS-002/A/JA/02/2019 dated February 21, 2019 concerning the Pattern of Handling of Special Crime Cases with Quality. In order to be realized optimally in order to strengthen the commitment of the Prosecutor's Office in law enforcement that is good, correct and reliable for the success of the national development program: ${ }^{37}$

1) Realizing a uniform pattern of handling cases of Special

2) Crimes as a unified system or working method in handling cases of Special Crimes integrally from the acceptance stage of the public complaint report, making a review, investigation stage, investigation stage, pre-prosecution stage, prosecution stage, trial stage, stage ordinary legal remedies, the stage of implementing the decision (execution), the extraordinary legal remedy stage, and the examination stage.

3) Referring to the Letter of the Deputy Attorney General for Special Crimes Number: B-845/F/Fjp/05/2018 dated 4 May 2018 concerning Technical Guidelines for the Handling of Quality Special Crime Cases.

The pattern of handling special criminal cases is a system or working rule in handling special criminal cases that are integrated with one another including receiving public reports/complaints, investigations, investigations, pre-prosecutions, prosecutions, trials, extraordinary legal remedies, executions, examinations, which is compiled based on the results of analysis and synchronization of pre-existing technical guidelines and the results of evaluation, monitoring and evaluation of the implementation of the duties and functions of the ranks of special crimes, both at the attorney general's office, high prosecutor's office, state prosecutor's office, and branch of the state prosecutor's office.

The Prosecutor's Office of the Republic of Indonesia is a government institution that exercises state power in the field of prosecution and other authorities based on the law. The prosecutor's office as a government institution in carrying out the duties, functions and authorities of criminal law enforcement both in a retroactive and preventive manner is a maximum effort in order to achieve community protection and achieve community welfare as reflected in the preamble of the 1945 Constitution and national development policies.

The strategic correlation between law enforcement and national development policies can be implemented by the ranks of special criminal acts by making efforts to prevent and prosecute special crimes. As follows: ${ }^{38}$

a. Consolidating with other law enforcers in the context of efforts to eradicate corruption and other special crimes.

b. Taking action against corruption and other special crimes as well as looking for the root causes of the factors causing corruption and other special crimes.

c. The prosecution of criminal acts of corruption and other special crimes is not only oriented to punishment/corporal punishment, but also to saving/recovering state financial losses.

d. The prosecution of criminal acts of corruption focuses on 10 areas prone to corruption, areas prone to corruption, namely;

- Procurement sector of goods and services

- Finance and banking sector

\footnotetext{
37 the instruction of the attorney general of the republic of indonesia number: ins-002/a/ja/02/2019 dated February 21,2019 concerning the pattern for handling qualified special criminal cases.

${ }^{38}$ sejampidsus $2018 \mathrm{~b}-845$ technical guidelines for handling high quality special criminal cases
} 


\section{Handling of Quality Corruption Case by the Prosecutor as Part of Prevention Measure}

- Tax sector

- Oil and Gas Sector

- BUMN/BUMD Sector

- Customs and excise sector

- Sector using APBN/APBD, APBN-P/APBD-P

- State/regional asset sector

- Forestry and mining sector

- Public service sector

e. The handling of special criminal cases is based on an independent attitude, not selective, thorough, clean and without fear. ${ }^{39}$

The implementation of the Prosecutor's Office in terms of eradicating and preventing Corruption Crimes is as follows:

1. Formation of the Government Guard and Security Team and the Development of the Republic of Indonesia Attorney's Office (TP4 or TP4D). The basis for the formation of the TP4 is the Decree of the Attorney General of the Republic of Indonesia Number: KEP-152/A/JA/10/2015 dated October 1, 2015. The purpose of its formation is to guard and secure the success of government and development. This team has duties and functions, namely:

a) Guarding, securing and supporting the success of government and development through preventive/preventive and persuasive efforts at both the central and regional levels according to their respective jurisdictions;

b) Can provide legal assistance in every stage of the development program from start to finish;

c) Coordinate with the Government's Internal Supervisory Apparatus to prevent irregularities that have the potential to hinder, thwart and cause losses to state finances;

d) Together to monitor and evaluate the implementation of work and development programs;

e) Carry out repressive law enforcement when sufficient initial evidence is found after coordination with the Government Internal Supervisory Apparatus regarding unlawful acts, abuse of authority and/or other actions that result in causing losses to state finances.

Looking at the main focus of President Jokowi's administration is "development and strengthening of the economic sector. The Prosecutor's Office then translated into the formation of the TP4 Team to oversee and secure the government and development carried out by the government. Judging from the duties and authorities as well as the composition of the sections/fields in the Team (consisting of elements of the Prosecutor's Intelligence, Civil and State Administration and Special Crimes), this team has described the functions of prevention and prosecution in efforts to eradicate corruption. Here the Prosecutor's Office is careful in establishing the legal policy, returning criminal law to its main essence as a last resort (ultimate remedium principle). However, there are still gaps in deviations in the form of potential TP4 as a halal stamp, the potential for sharing commitment fees,

Regarding prosecution. Several regulations related to case handling were issued, including: Circular Letter of the Junior Attorney General for Special Crimes (SE-JAMPIDSUS) Number: B-260/F/Fd.1/02/2018 dated 12 February 2018 regarding Performance and Quality Improvement in case handling. The circular letter is a continuation of the Memorandum of Understanding between the Ministry of Home Affairs and the Attorney General's Office of the Republic of Indonesia and the Indonesian National Police. The essence of the circular letter is related to sufficient initial evidence, related to the pattern of relations between APIP and APH, related to support for the implementation of corruption prevention and eradication actions.

There are interesting things from the letter in the discussion of point 3 , namely:

1. There is a priority for handling large-scale cases (big fish) and focusing on returning cases. ${ }^{40}$

\footnotetext{
39 ibid

${ }^{40}$ Try to compare it with the circular letter of the junior attorney general for special crimes (se-jampidsus) number: 1113/f/fd.1/05/2010 dated 18 may 2010 concerning priorities and achievements in handling corruption cases. there are several similarities, namely both prioritizing large-scale cases (big fish) and prioritizing the return of state finances which in se-jampidsus number: 1113 uses the term restorative justice approach. in fact, the focus on recovering state financial losses is one of the goals of eradicating corruption which aims to restore, in this case, restore state finances that were previously in the hands of those who were not supposed to be. in se-jampidsus b-number: 260 does not include cases that are carried out on a continuous scale (still going on) such as extortion as in se-jampidsus number: 1113. in fact, extortion is one of the issues that became the focus of president jokowi during his reign. the parameters of corruption cases categorized as big fish are based on the circular
} 


\section{Handling of Quality Corruption Case by the Prosecutor as Part of Prevention Measure}

2. There is consideration for the return of state financial losses at the investigation level on the basis of the usefulness of the handling process and the smooth running of national development. ${ }^{41}$

The follow-up to SE-JAMPIDSUS B-Number: 260 was then issued a Circular Letter from the Deputy Attorney General for Special Crimes (SE-JAMPIDSUS) Number: B-765/F/Fd.1/04/2018 dated April 20, 2018 regarding technical guidelines for handling investigation stage of corruption cases. In this circular letter again emphasizes the consideration of the return of state financial losses at the investigation level on the basis of the interests of the stability of the local regional government and the smooth running of national development.

As for SE-JAMPIDSUS B-Number: 260 and SE-JAMPIDSUS Number: 760, are legal policies that use an economic approach to law (Economy Approach to Law) as a material for consideration, this is in line with the government's main agenda which prioritizes aspects of accelerating development. . However, there are several issues that have become a problem, related to the termination of the investigation on the basis of returning state financial losses not in accordance with Article 4 of the PTPK Law which essentially states that returning state financial losses does not erase the sentence. Do not let the good intentions of policy makers who are already thinking progressively by applying the principle of expediency and the principle of proportionality as the main reference, serve as an arena for corruption by irresponsible persons.

Technical guidelines for handling high quality special criminal cases Based on the Circular Letter of the Junior Attorney General for Special Crimes (SE-JAMPIDSUS) Number 845/F/Fjp/05/2018 Dated May 4, 2018 regarding the Technical Guidelines for the Handling of Quality Special Crime Cases. The purpose of issuing this circular is to realize quality case handling and prevent irregularities in handling special criminal cases. The contents relate to the criteria for maximum law enforcement through preventive and repressive efforts. Some of these criteria include:

1. Build a zone free of corruption;

2. Coordination with other law enforcement officers;

3. Cooperation with religious organizations, educational institutions, mass media, NGOs, in order to increase the role of the community;

4. Efforts to take action by looking for the root of the problem and the factors causing the deviation;

5. Enforcement efforts that are not only oriented towards criminalizing the body but also restoring state financial losses (restorative);

6. Enforcement by focusing on 10 (ten) corruption-prone points, namely: the procurement of goods/services, the financial and banking sector, the taxation sector, the oil and gas sector, the BUMN/BUMD sector, the Customs and excise sector, the sector using the APBN/APBD, the state asset sector/ regional, forestry/mining sector, public service sector;

7. Actions that are not selective and complete without fear (clean and fearless);

8. Handling cases in accordance with the applicable Standard Operating Procedures (SOP). ${ }^{42}$

The prosecutor's office in efforts to eradicate corruption has sought law enforcement, both carried out with preventive efforts and carried out with enforcement efforts. The prosecutor's efforts in eradicating corruption are in line with Jokowi's

letter of the junior attorney general for special crimes (se-jampidsus) number 845/f/fjp/05/2018 dated may 4, 2018 regarding the technical guidelines for the handling of quality special crime cases

1. Perpetrators of criminal acts are state administrators as referred to in law number 28 of 1999 concerning government organizers that are clean and free of kkn;

2. Involve actors and one and/or more ministries/institutions together with actors in legislative and/or judicial institutions and/or other high state institutions, both centrally and regionally with private actors;

3. violation of one or more laws and regulations in different regulatory fields;

4. Evidence using conventional evidence, article 184 of the criminal procedure code plus digital evidence and/or financial evidence or scientific evidence;

5. Crimes committed during a disaster; 6 . incurring state financial losses above 10 billion for the offense of article 2 paragraph (1) or article 3 of the ptpk law,

${ }^{41}$ that the policy makers include the return of state financial losses at the investigation level as part of the consideration in the process of handling cases on the basis of the benefits and smoothness of development, shows that policy makers emphasize the economic aspects of the law, this is seen from the basis of consideration of the benefits and smoothness of development. here policy makers understand and harmonize the government's goals which prioritize development aspects.

${ }^{42}$ standar operasional prosedur (sop) tindak pidana khusus diatur dalam peraturan jaksa agung republik indonesia nomor : perja-039/a/ja/10/201 tanggal 29 oktober 2010 tentang tata kelola administrasi teknis penanganan perkara tindak pidana khusus. 


\section{Handling of Quality Corruption Case by the Prosecutor as Part of Prevention Measure}

government policies, which strengthen the role of law enforcement officials who have law enforcement authorities related to eradicating corruption in the context of initial coordination, restoring the application of law by placing crime as the ultimumremedium (prioritizing administrative efforts). The prosecutor's legal policy as explained above is an order of legal substance that will be maximized, if it is supported by human integrity, both law enforcers themselves and the community. As legal experts say:

Taverne who said:

"Give me good prosecutors and judges, so even bad laws can make good decisions."

As this expression becomes a philosophical value, legal policies, both through laws and instructions and rules of legal institutions, will be returned to the applicators/actors who are tasked with and mandated by the people and the state to create a state and implement a free state administration. from all evil acts of corruption, collusion, and nepotism that damage and hinder the development of the Indonesian nation both in terms of human quality and quantity caused by acts of corruption.

\section{CLOSING}

\section{A. CONCLUSION}

From the explanation above, the writer can conclude as follows:

1. The Prosecutor's Office of the Republic of Indonesia as a government institution indirectly in making legal policies is based on the policies taken by the government and the related legal basis. As for some of the prosecutor's policies in dealing with quality corruption cases through institutional policies that are based on both handling procedures, division of focus on areas prone to corruption,

2. Related to enforcement with several regulations (SE-JAMPIDSUS) regarding quality technical guidelines for handling special criminal cases, the purpose of this circular is to realize quality case handling and prevent irregular practices in handling special criminal cases. The contents relate to the criteria for maximum law enforcement through preventive and repressive efforts and without selective discrimination, as well as several criteria for eradicating corruption by building a corruptionfree zone through strengthening the awareness of individuals and groups of state institutions, eradicating corruption to the root of the problem and looking for the factors causing it. , and carry out the handling of corruption cases in accordance with procedures.

\section{B. SUGGESTION}

From the discussion above, the writer gives the following suggestions:

1. Handling corruption cases as part of prevention efforts, it is quite relevant indeed to handle corruption cases to prevent increasing state losses, but we must change our paradigm of thinking about how to eradicate corruption and eliminate all corruption problems that are rooted in this republic. Not only by handling cases but by realizing the implementation of a state that is free from corruption problems. To achieve this, there must be severe sanctions for the perpetrators of corruption, not by punishment, but by seizing all the wealth that the perpetrators of corruption have and revoking their political rights, in order to deter them because if they are only punished while they have sufficient financial resources, they can feel like living in a prison like living in their own home with luxurious facilities that they pay for it must be realized together because the executors of the authority to take care of correctional institutions can still be bribed with money because of the value of welfare those who are low. Firmness in law enforcement and the strength of legal sanctions from criminal acts of corruption are deemed very necessary to eradicate corruption in Indonesia which is increasingly worrying.

\section{BIBLIOGRAPHY}

Books:

1) AtmasasmitaRomli, Strategy for Guiding Criminals in the Context of Law Enforcement in Indonesia. (Bandung: Alumni, 1982), p.

2) AstasasmitaRomli, Integrative Legal Theory, Second Edition, Genta Yogyakarta, 2012.

3) Dellyana, Shant, Concept of Law Enforcement, (Liberty: Yogyakarta, 1988).

4) Friedmann L., The Legal System: A Social Science Perspective, Rusel Sage Foundstions, New York, 1975.

5) Muladi, Capita Selecta of the Criminal Justice System. (Semarang: Diponegoro University Publishing Agency, 2002).

6) Marzuki Mahmud Peter (A), Legal Research Revised Edition, 12th Printing, (Jakarta: Prenada Media Group, 2016).

7) Borrowing the term "development" put forward by MochtarKusumaatmadja, Functions and Development 


\section{Handling of Quality Corruption Case by the Prosecutor as Part of Prevention Measure}

8) of Law in NationalDevelopment, 1976, Binacipta, Bandung.

9) Mattei Ugo, Theer Patterns of Law: Taxonomy and Change in The World's New Constitutions,

10) The American Journal of Comparative Law, 1997.

11) Saihu Mohammad, Law Summit III: Eradicating KKN indiscriminately to its roots March-April Edition, (Jakarta: KHN Newsletter 2004).

12) Yahya Harahap M. Discussion of Problems and Implementation of the Criminal Procedure Code. (Jakarta: Sinar Graphic, 2002).

\section{Constitution:}

1) Law of the Republic of Indonesia Number 16 of 2004 Article 30 Paragraphs (1).

2) Law of the Republic of Indonesia Number 16 of 2004 concerning the Prosecutor's Office of the Republic of Indonesia.

3) The Instruction of the Attorney General of the Republic of Indonesia Number: INS-002/A/JA/02/2019 dated February 21, 2019 concerning the Pattern for Handling Qualified Special Criminal Cases.

4) Presidential Instruction of the Republic of Indonesia Number 9 of 2011, Instruction of the President of the Republic of Indonesia Number 17 of 2011

5) Sejampidsus 2018 B-845 technical guidelines for handling high quality special criminal cases

6) Standard Operating Procedures (SOP) for Special Crimes are regulated in the Regulation of the Attorney General of the Republic of Indonesia Number: PERJA-039/A/JA/10/201 dated October 29, 2010 concerning the Technical Administration of the Handling of Special Crimes.

7) Government Report on Implementation of State Revenue and Expenditure Budget 2014 Fiscal Year, Republic of Indonesia, 2014.

\section{Journals / Papers:}

1) Try to compare it with the Circular Letter of the Junior Attorney General for Special Crimes (SE-JAMPIDSUS) Number: 1113/F/Fd.1/05/2010 dated 18 May 2010 concerning Priorities and Achievements in handling corruption cases. There are several similarities, namely both prioritizing large-scale cases (Big Fish) and prioritizing the return of state finances which in SE-JAMPIDSUS Number: 1113 uses the term restorative justice approach. In fact, the focus on recovering state financial losses is one of the goals of eradicating corruption which aims to restore, in this case, restore state finances that were previously in the hands of those who were not supposed to be. In SE-JAMPIDSUS B-Number: 260 does not include cases that are carried out on a continuous scale (still going on) such as extortion as in SE-JAMPIDSUS Number: 1113. In fact, extortion is one of the issues that became the focus of President Jokowi during his reign. The parameters of corruption cases categorized as Big Fish are based on the Circular Letter of the Junior Attorney General for Special Crimes (SE-JAMPIDSUS) Number 845/F/Fjp/05/2018 dated May 4, 2018 Regarding the Technical Guidelines for the Handling of Quality Special Crime Cases

2) Perpetrators of criminal acts are state administrators as referred to in Law Number 28 of 1999 concerning Government Organizers that are Clean and Free of KKN; Involve actors and one and/or more ministries/institutions together with actors in legislative and/or judicial institutions and/or other high state institutions, both centrally and regionally with private actors;

3) Violation of one or more laws and regulations in different regulatory fields;

4) Evidence using conventiona I evidence, Article 184 of the Criminal Procedure Code plus digital evidence and/or financial evidence or scientific evidence;

5) Crimes committed during a disaster

6) ; 6. Incurring state financial losses above 10 billion for the offense of Article 2 paragraph (1) or Article 3 of the PTPK Law,

7) That the policy makers include the return of state financial losses at the investigation level as part of the consideration in the process of handling cases on the basis of the benefits and smoothness of development shows that policy makers emphasize the economic aspects of the law, this is seen from the basis of considerations of the benefits and smoothness of development Here policy makers understand and harmonize the government's goals which prioritize development aspects.

8) The Indictment of the Public Prosecutor in the Corruption Case of PT Asuransidiwasraya. Tbk. 


\section{Handling of Quality Corruption Case by the Prosecutor as Part of Prevention Measure}

9) LPIKP, another Side of the Accountability of the KPK and Anti-Corruption Activist Institutions, Gramedia Pustaka Utama, 2016, Jakarta.

10) KoesoemoTirzaniRizka Cindy, The existence of the Corruption Eradication Commission (KPK) in handling the investigation and prosecution of criminal acts of corruption, published in the Journal of Lex Crimen Volume. VI/Number. 1/Jan-Feb/2017.

11) Setiadi Edi, Enforcement of Criminal Law against Corruption Cases in Creating Clean Government, published in the Pulpit Journal Number. 4th XVI Oct. - Dec. 2000.

Internet:

1) Asrianto Zainal, Law Enforcement of Corruption Crimes by the Attorney General's Office, published in ejournal.iainkendari.ac.id al-izzah article view, accessed on 09 March 2021, at 09:30 WIB.

2) AsniOvier, Attorney General: In order to have a deterrent effect, law enforcement must follow the assets, published inhttps://www.beritasatu.com/nasional/702149/jaksa-agung-agar-ada-hasil-jera-penegakan-hu kumharus-follow-the-asset, accessed on March 21, 2021, at 20:25 WIB

3) Murwiyanto, Effectiveness of the Prosecutor's Office in Eradicating Corruption Crimes and Refunding State Losses Due to Corruption, published in

4) https://dspace.uii.ac.id/bitstream/handle/123456789/9136/TESIS\%20MURWIYANTO.pdf?sequence=1\&isAllowe $\mathrm{d}=\mathrm{y}$, accessed on 01 March 2021.

5) Muhammad Afzal, Effectiveness of Corruption Enforcement in the Aceh High Court Based on Law no. 20 of 2001", publishedin https://repository.ar-raniry.ac.id/id/eprint/15315/1/Muhammad\%20Afzal\%2C\%20140106038\%2C\% 20FSH\%2C\%20IH\%2C\% 2008216 7420403.pdf, accessed on March 10, 2021, at 14:30 WIB.

6) Central Jakarta District Court, "SIPP - Central Jakarta District Court ,http://sipp.pn-jakartacenter.go.id/index.php/detil perkara, accessed on March 20, 2021, at 21:30 WIB.

7) Central Jakarta District Court Number: 30/Pid.Sus-TPK/2020/PN.Jkt.Pst dated 22 May 2020, Central Jakarta District Court Number: 32/Pid.Sus-TPK/2020/PN.Jkt.Pst 22 May 2020, Central Jakarta District Court Number: 33/Pid.Sus-TPK/ 2020/PN.Jkt.Pst dated May 22, 2020, and Central Jakarta District Court Number: 34/Pid.SusTPK/2020/PN.Jkt.Pst May 27, 2020 ;

8) The Attorney General's Team, Speech by the Attorney General at the Opening Ceremony of the 2018 Technical Working Meeting for Special Crimes, was published in https://www.kejaksaan.go.id/pidato.php ?idu=0\&id=206\& p=8, accessed on March 15, 2021.

9) Tsarina Maharani, Jiwasraya Corruption Case Investigation, AGO confiscates IDR 18.4 Trillion Assets, published in https://national.kompas.com/read/2020/07/02/17221671/investigation-case-korupsi-jiwas Raya-kejagung-sitaasset-Rp-184-trillion, accessed on March 17, 2021, at 17:30 WIB. 